\title{
Bireylerin Tıbbi-Aromatik Bitki Tüketimini Etkileyen Faktörlerin Belirlenmesi: Erzurum Merkez İlçeleri Örneği
}

\section{Determining the Factors Affecting the Medicinal-Aromatic Plant Consumption of Individuals: The Case of Erzurum Central Districts}

\author{
Rüveyda Yüzbaşığlu a* \\ ${ }^{a}$ Dr. Öğr. Üyesi, Tokat Gaziosmanpaşa Üniversitesi, Ziraat Fakültesi, Tarım Ekonomisi Bölümü, Tokat/Türkiye \\ ORCID: 0000-0002-6520-0543
}

\section{MAKALE BİLGİSI}

\section{Makale Geçmişi:}

Başvuru tarihi: 10 Nisan 2018

Düzeltme tarihi: 03 Ocak 2019

Kabul tarihi: 22 Ocak 2019

\section{Anahtar Kelimeler:}

Bilinç Düzeyi

Binary Kogit

Tercih

Tıbbî Aromatik Bitkiler

Tüketim

\section{ARTICLE INFO}

\section{Article history:}

Received 10 April 2018

Received in revised form 03 January 2019

Accepted 22 January 2019

\section{Keywords:}

Awareness Level

Binary Logit

Preferences

Medical Aromatic Plants

Consumption

\section{ÖZ}

Bu çalışmada, Erzurum İli merkez ilçelerinde (Aziziye, Palandöken ve Yakutiye) kentsel alanda yaşayan bireylerin tükettikleri tıbbi ve aromatik bitkileri bilinçli olarak mı tüketildiği ya da ne amaçla tükettiklerini belirleyip ve tüketimi etkileyen faktörlerin belirlenmesi amaçlanmıştır. Araştırma kapsamın görüşülen 384 bireyin ortalama yaşı 35,19, \%63.80'ni erkek, \%73,70'inin evli ve \%58,85'nin çocuğu olduğu belirlenmiștir. Araştırmada bireylerin tıbbi aromatik ürünleri bilinçli tüketimini etkileyen faktörleri binary logit analizi yardımı ile belirlenmeye amaçlanmıştır. Analiz sonuçları bireylerin cinsiyeti, çocuk sahibi olma durumu, medeni durumu, hanedeki fert sayısı ve eşlerin çalışma durumu ile tıbbi aromatik bitki tüketimindeki bilinçli olma durumu arasında anlamlı bir ilişki ortaya konulmuştur. Araştırma sonucunda söz konusu bölgede bireylerin tıbbi aromatik bitkileri tüketimi bilinç düzeyi çok düşük olmamakla beraber tercih de kadınların ve yanlız yaşayanların daha çok tüketmeye meyilli olduğu söylenebilir.

\begin{abstract}
A B S T R AC T
This study aimed to determine the medicinal and aromatic plant consumption of individuals living in the central urban districts (Aziziye, Palandöken, and Yakutiye) of Erzurum province and the factors affecting their consumption. The data of the study were collected through a questionnaire. The mean age of the interviewed individuals of 384 was found to be $35,19.63,80 \%$ were male, $73,70 \%$ were married, and $58,85 \%$ had children. In the study, the factors affecting the consumption of medicinal aromatic plants were determined using binary logit analysis. As a result of the analysis, while individuals' gender, having children, the marital status, the number of households, the employment status of spouses of individuals who were found to be significant with consciousness level in terms of medicinal aromatic plant consumption. As a result of the research, it can be stated that while the consciousness level of individuals in the region was not very low in terms consumption of medicinal aromatic plants, women, and individuals living alone tended to consume these products more.
\end{abstract}

\section{Giriş}

Tıbbi ve aromatik bitkiler; insanoğlunun daha sağlıklı bir yaşam sürmesi veya çeşitli hastalıklara karşı korumak ve iyileştirmek için kullanılmaktadır. Tıbbi ve aromatik bitkiler, en çok gida olarak tüketilmekle birlikte ilaç, kozmetik, vücut bakımı, tütsü veya dini törenler ve benzer amaçlarla da

\footnotetext{
* Sorumlu yazar/Corresponding author
} e-posta: ruveyda.kiziloglu@gop.edu.tr kullanılmaktadır (Lewin, 2000; Heinrich ve ark., 2004; Bayram ve ark., 2010; Faydaoğlu ve Sürücüoğlu, 2011).

Türkiye'de tıbbi aromatik bitkilerin tüketim şekilleri tam anlamıyla bilinmemekle birlikte, Botanik ve Eczacılık eğitimi görmemiş yazarlar tarafından çeviri veya derleme şeklinde hazırlanan ya da pek çok geleneksel hekimlik uygulaması mevcuttur. Buna karşılık tıbbi bitkiler, hasta 
tedavisinde kullanıldığı gibi sağlıklı yaşam için de tamamlayıcı ya da destekleyici ürün olarak tercih edilebilmektedir (Dicle, 2010).

Literatür incelendiğinde yurt içi ya da yurt dışında tüketicilerin tıbbi aromatik bitkilere karşı davranışları ya da aktarlardan satın alma-satımı incelenmiştir (Demirci ve ark., 2007; Dicle, 2010; Faydalığlu ve Sürücü, 2011; Arya ve ark., 2012; Çelik, 2014; Kökçü ve ark., 2015; Adıgüzel ve Kızılaslan, 2016; Akbulut ve Özkan, 2016; Demirçivi ve Altaş, 2016; Kocabaş ve Gedik, 2016; Yüzbaşığlu ve Ataoğlu, 2018). Ancak gerek yurt içi gerek yurt diş1 çalışmalarında tüketim veya tıbbi aromatik bitki tüketimini etkileyen faktörler istatistiki olarak incelenmediği gözlenmiş, bu araştırma ile belirlenmeye çalışılmıştır.

Bireyler çeşitli nedenlerden dolayı bilerek ya da bilmeyerek bir şekilde gündelik hayatlarında en az bir tıbbi aromatik ürünlerden en az bir kere kullanmaktadır. Bireylerin tıbbi ve aromatik bitkiyi bilerek mi yoksa alışkanlıktan ya da damak tadı olarak mı kullandığını belirlemek yani bireylerin bilinçli bir tüketici mi olduğunu ortaya koymak bu araştırmanın temel amacını oluşturmaktadır. Ayrıca önceki literatürler incelendiğinde istatistiki olarak tıbbi ve aromatik bitkilerin bilinçli olarak tüketimini belirleyen bazı durumları ortaya koyan araştırmanın olmaması da bu araştırmanın önemini artırmaktadır. Bu çalışma ile Erzurum İli merkez ilçelerinde (Aziziye, Palandöken ve Yakutiye) kentsel alanda yaşayan bireylerin tıbbi ve aromatik bitki tüketimi ile bu ürünlerin bilinçli olarak tüketimini etkileyen faktörlerin belirlenmesi amaçlanmıştır.

Araştırma üç bölümden oluşmaktadır. Birinci bölümde bireylerin sosyo-demografik özellikleri ortaya konulmuştur. İkinci bölümde bireylerin tıbbi aromatik bitkileri bilme, hangi bitkileri kullandığı ve ne amaçla kullandığ konulmaktadır. Son bölüm bireylerin tıbbi ve aromatik bitki tüketimini etkileyen bazı özelliklerini istatistiki olarak ortaya koymayı kapsamaktadır.

\section{Materyal ve Yöntem}

\subsection{Materyal}

Erzurum İli merkez ilçelerinin kentsel alanlarında yaşayan bireylerle yüz yüze görüşülerek bu araştırmanın ana materyali elde edilmiştir. Ayrıca önceki literatür kaynaklarından da yararlanılmıştır.

\subsection{Verilerin Toplanması Aşamasında İzlenen Yöntem}

Toplam popülasyonuen iyi düzeyde temsil edilecek örneklem büyüklüğünün belirlenmesinde oransal yaklaşımdan yararlanılmıştır.

$\mathrm{n}=\frac{N p(1-p)}{(N-1) \sigma_{p}^{2}+p(1-p)}$

n= örnek büyüklüğü,

$\mathrm{N}=$ populasyon büyüklüğü,

$\mathrm{p}=$ tahmin oranı (0,5 maksimum örnek büyüklüğü için), (Miran, 2003; Kızıloğlu ve Kızılaslan, 2017) $\sigma_{p}^{2}=$ oran varyansı (maksimum örnek hacmine ulaşmak için $\% 95$ güven aralığında tablo değeri 1,96 ve \%5 hata payı ile). Ana kitleyi oluşturan bireylerin özellikleri başlangıçta bilinmediği için, örnek hacmini maksimum kılacak şekilde $\mathrm{p}=0,5$ olarak alınmış ve örnek hacmi 384 birey olarak bulunmuştur. Görüşülecek bireylerin sayısının belirlenmesinde, yerleşim birimlerinin toplam popülasyon içindeki payları esas alınmış (Kızıloğlu ve Kızılaslan, 2013) ve örneğe alınan bireyler tesadüfi olarak belirlenmiştir.

Tablo 1'de Erzurum şehrinin merkeze bağlı üç ilçesinin nüfusu, toplamdaki oranı ve örnek hacmindeki dağılımı verilmiştir. Merkez ilçelerin toplamı 417,385 olarak belirlenmiş ve bu oran içinde merkez ilçelerin nüfuslarına göre oranları ortaya konulmuştur. Oransal örnekleme ile belirlenen sayı, bu oranlar doğrultusunda rastgele bir dağıtım yapılarak ilçelerdeki örnek hacmi belirlenmiştir.

Tablo 1. Erzurum İli Nüfusu (2016)

\begin{tabular}{lccc}
\hline & Nüfus (N) & Oran (\%) & $\begin{array}{c}\text { Örnek } \\
\text { Hacmi (n) }\end{array}$ \\
\hline Aziziye & 57,092 & 13,68 & 53 \\
Palandöken & 168,430 & 40,35 & 155 \\
Yakutiye & 191,863 & 45,97 & 177 \\
Erzurum & 417,385 & 100,00 & 384 \\
(Merkez) & & & \\
\hline
\end{tabular}

\subsection{Verilerin Analizi Aşamasında İzlenen Yöntem}

Araştırmada bireylerin tıbbi ve aromatik bitkilerin tüketimini etkileyen faktörler binary logit model yardımı ile belirlenmiştir. Nitekim; bireylerin çeşidi fazla olan tıbbi aromatik bitkilerin en az birini tüketeceği varsayımından yola çıkarak ve bilinçli bireylerin tüketim olasılıklarını ortaya koymak, bilinç düzeyini belirleyici sorular (Tıbbi aromatik bitkiyi doğru ve yanlış tanımlayacak ifadeler) sorulmuştur. Böylelikle modelin bağımlı değişkeni olan doğru tanımlayan (bilinçli) bireyler ve yanlış tanımlayan (bilinç seviyesi düşük) bireyler belirlenmiştir.

Soruların cevaplarına ise puanlar verilmiş ve bu puanlar toplanmıştır. Tam puan, 5 olarak hesaplanmıştır. Tam puanın yarısına denk gelen 2,5 üstü puan alan bireyler, bilinçli olarak değerlendirilmiş ve 1 olarak kodlanmış, 2,5 altı puan olan bireyler bilinçsiz olarak değerlendirilmiş ve 0 olarak kodlandırılmıştır. Bilinç düzeyini belirleyici sorular ve puanları Tablo 3 'te verilmiştir.

Tıbbi aromatik ürünleri tüketimini etkileyecek bazı sosyodemografik değişkenler binary logit modeli yardımı ile belirlenmiştir. Logit modelinde bağımlı değişken kukla ve tahmin edilen olasılık değerleri 0 ile 1 olarak kodlanmıştır. Lojistik fonksiyon (LOGIT) genel formülü (Gujarati, 1992);

$F_{i}\left(\beta X_{i}\right)=\frac{\exp \left(\beta X_{i}+\varepsilon_{i}\right)}{1+\exp \left(\beta X_{i}+\varepsilon_{i}\right)}$

$\mathrm{F}\left(\beta \mathrm{X}_{\mathrm{i}}\right)=$ İndex fonksiyonunu (1nci bireyler için gözlenen tıbbi aromatik ürünleri tüketimi, bilinçli tüketmeyenler için $\mathrm{j}=0$; bilinçli tüketenler için $\mathrm{j}=1$ )

$\beta=$ Açıklayıcı değişkenlerin katsayı vektörünü,

$\mathrm{X}_{\mathrm{i}}=$ Bireylerin karakterlerini temsil eden açıklayıcı değişkenleri, 
$\varepsilon_{\mathrm{i}}=$ Hata terimini göstermektedir.

Bireylerin tıbbi aromatik ürünleri bilinçli tüketme olasılığı:

$$
\begin{aligned}
& \mathrm{P}_{\mathrm{i}}=\frac{1}{\left.1+e^{-z_{i}}\right]} \\
& \mathrm{P}_{\mathrm{i}}=\text { Bağımlı değişkenin olma olasılığ } \\
& e=\text { doğal logaritma } \\
& Z_{i}=\beta X_{i} Z_{i} Z_{i}=\beta_{1}+\beta_{2} X_{2}
\end{aligned}
$$

tıbbi aromatik ürünleri bilinçsiz tüketme olasılığg ise $\left(1-\mathrm{P}_{\mathrm{i}}\right)$ formülü;

$$
\frac{P_{i}}{1-P_{i}}=\frac{1+e^{+z_{i}}}{\left[1+e^{-z_{i}}\right]}=e^{z_{i}}
$$

tıbbi aromatik ürünleri bilinçli tüketme bahis oranı olan formülün doğal logaritması alınırsa aşağıdaki sonuca ulaşılır.

$$
\mathrm{L}_{\mathrm{i}}=\ln \frac{P_{i}}{1-P_{i}} Z_{i}=\beta_{1}+\beta_{2} X_{2}
$$

Bahis oranının logaritması L, yalnız X'e göre değil, ana kitle katsayılarına göre de doğrusaldır. L'ye logit denir ve logit modeli formülden gelmektedir (Gujarati, 1992).

Açıklayıcı değişkenler, gözlemlenen değişkenlerden çıkartılmaktadırlar ve onların doğrusal bileşenleri olarak tahmin edilebilirler. J'inci faktör olan $F_{j}$ 'in genel tahmin eşitliği şu şekilde ifade edilebilir:

$$
F_{j}=\sum_{i=1}^{p}\left[W_{j i} X_{1}+W_{j} X_{2}+\ldots+W_{j p} X_{p}\right]
$$
$\mathrm{W}_{\mathrm{i}}$ : Açıklayıcı değişkenler skor katsayılarını
P: değişken sayısını göstermektedir (Berenson ve Levine, 1996; Akgül ve Çevik, 2005).
Lojistik modelde yer alan bazı değișkenler, kategoriler arası farklılıkları olasılık oranları olarak elde edilebilmek üzere kategorik değişkene çevrilmiştir. Bağımlı değişken ile ilişkilendirilmesi yani açıklaması daha kolay ya da anlaşılır olması için açıklayıcı değișkenler kukla değişken halinde modele alınmıştır.

Modele açıklayıcı değişken olarak; bireylerin yaşı (sürekli değişken), cinsiyet (kadın ise 0 , erkek ise 1 olarak kodlanmıştır), medeni durum (bekar ise 0 , evli ise 1 olarak kodlanmıştır), eğitim durumu(lise ve lise altı ise 0 , lise üstü ise 1 olarak kodlanmıştır), eşinin çalışma durumu (çalışmıyorsa 0 ile çalışıyorsa 1 ile kodlanmıştır), bireylerin aylık gelirleri (sürekli değişken), hanedeki fert sayısı (sürekli değişken), çocuk sahibi olma (çocuk sahibi ise 1 , değilse 0 olarak kodlanmıştır), bireylerin, kalp, tansiyon, kolesterol, şeker ve böbrek rahatsızlığı olma durumu (rahatsız var ise 1, yok ise 0 olarak kodlanmıştır)ve herhangi bir rahatsızlığı için ilaç niyetine tıbbi aromatik bitki tercih etme durumu (tercih ediliyorsa 1 , edilmiyor ise 0 olarak kodlanmıştır) dahil edilmiştir.

\section{Bulgular ve Yorumlar}

\subsection{Bireylerin Genel Özellikleri}

Araştırma kapsamında görüşülen bireylerin bazı sosyoekonomik ve demografik özellikleri Tablo 2'de gösterilmiştir. Bireylerin \%36,20'si kadın, \%63,80'i erkektir. Bireylerin \%73,70'i evli, \%39,84'nün eşlerinin çalıştığı ve hanede ortalama 3,50 birey yaşamakta olup bireylerin \%41,15'i çocuk sahibi olduğu Tablo 2'de

\begin{tabular}{|c|c|c|c|c|c|}
\hline \multicolumn{2}{|l|}{ Değişken Tanımları } & \multirow{2}{*}{$\begin{array}{c}\text { Frekans } \\
235 \\
\end{array}$} & \multirow{3}{*}{$\begin{array}{c}\% \\
61,20 \\
38,80\end{array}$} & \multirow[t]{3}{*}{ Ortalama } & \multirow{3}{*}{$\begin{array}{c}\begin{array}{c}\text { Standart } \\
\text { Sapma }\end{array} \\
0,488\end{array}$} \\
\hline \multirow{2}{*}{ Bağımlı Değişken $(\mathbf{Y})$} & Bilinçli tüketiyorsa:1 & & & & \\
\hline & Bilinçsiz tüketiyorsa:0 & 149 & & & \\
\hline Yaş (YAS) & & & & 35,19 & 10,237 \\
\hline Gelir (ay/TL) (GELIR) & & & & 2527,290 & 1217,083 \\
\hline \multirow{2}{*}{ Cinsiyet (CINSIYET) } & Kadın:0 & 139 & 36,20 & & \\
\hline & Erkek:1 & 245 & 63,80 & & \\
\hline \multirow{2}{*}{ Medeni Durum (MD) } & Bekar:0 & 101 & 26,30 & & \\
\hline & Evli:1 & 283 & 73,70 & & \\
\hline \multirow{2}{*}{ Eğitim Durumu (ED ) } & $\begin{array}{l}\text { Lise ve lise altı Mezunu } \\
\text { Olanlar:0 }\end{array}$ & 228 & 59,38 & & \\
\hline & $\begin{array}{l}\text { Lise üstü Mezunu } \\
\text { Olanlar: } 1\end{array}$ & 156 & 40,63 & & \\
\hline \multirow{2}{*}{$\begin{array}{l}\text { Eşinin Çalışma } \\
\text { Durumu (ESCALISM) }\end{array}$} & $\begin{array}{l}\text { Çalışmıyor (Emekli, İşsiz, } \\
\text { İş arıyor, öğrenci):0 }\end{array}$ & 231 & 60,16 & & \\
\hline & Çalışıyor:1 & 153 & 39,84 & & \\
\hline \multicolumn{2}{|c|}{ Hanedeki fert sayısı (FERT) } & & & 3,50 & 1,329 \\
\hline \multirow{3}{*}{$\begin{array}{l}\text { Çocuk Sahibi Olma } \\
\text { Durumu (COCUK ) }\end{array}$} & Çocuk sahibi olmayanlar:0 & 226 & 58,85 & & \\
\hline & Çocuk sahibi olanlar:1 & 158 & 41,15 & & \\
\hline & Olanlar:1 & 37 & 9,64 & & \\
\hline
\end{tabular}
görülmektedir. Görüşülen bireylerin ortalama yaşı 35,19 olarak bulunmuştur. Görüşülen bireylerin eğitim durumları incelendiğinde ise yarısından fazlasının $(\% 59,38)$ lise ve lise altı eğitim gördükleri belirlenmiştir. Bireylerin ortalama aylık geliri 2,527,290 TL olarak hesaplanmıştır.

Tablo 2. Bireylerin Genel Özelliklerine Ait Tanımlayıcı İstatistikleri 


\begin{tabular}{|c|c|c|c|}
\hline $\begin{array}{l}\text { Kalp Rahatsızlığının } \\
\text { Olma Durumu (KALP) }\end{array}$ & Olmayanlar:0 & 347 & 90,36 \\
\hline \multirow{2}{*}{$\begin{array}{l}\text { Tansiyon } \\
\text { Rahatsizlığının Olma } \\
\text { Durumu (TANSIYON) }\end{array}$} & Olanlar:1 & 74 & 19,27 \\
\hline & Olmayanlar:0 & 310 & 80,73 \\
\hline \multirow{2}{*}{$\begin{array}{l}\text { Şeker Rahatsızlı̆̆ının } \\
\text { Olma Durumu } \\
\text { (SEKER) }\end{array}$} & Olanlar:1 & 41 & 10,68 \\
\hline & Olmayanlar:0 & 343 & 89,32 \\
\hline \multirow{2}{*}{$\begin{array}{l}\text { Kolesterol } \\
\text { Rahatsılığının Olma } \\
\text { Durumu } \\
\text { (KOLESTER) }\end{array}$} & Olanlar:1 & 72 & 18,75 \\
\hline & Olmayanlar:0 & 312 & 81,25 \\
\hline \multirow{2}{*}{$\begin{array}{l}\text { Böbrek Rahatsızlı̆̆ının } \\
\text { Olma Durumu } \\
\text { (BOBREK) }\end{array}$} & Olanlar:1 & 67 & 17,45 \\
\hline & Olmayanlar:0 & 317 & 82,55 \\
\hline \multirow{2}{*}{$\begin{array}{l}\text { Herhangi bir } \\
\text { rahatsızlığı için ilaç } \\
\text { niyetine tıbbi aromatik } \\
\text { bitki tercih etme } \\
\text { durumu (ALTERNTF) }\end{array}$} & Tercih ediliyorsa 1 & 43 & 11,20 \\
\hline & Edilmiyor ise 0 & 341 & 88,80 \\
\hline
\end{tabular}

Bireylerin sağlık durumları Tablo 2'de görüldüğü üzere; \%9,64'ünün kalp rahatsızlığı, \%19,27'sinin tansiyon rahatsızlığı, \%10,68'nin şeker hastalığ 1 \%18,75'inin kolesterol rahatsızlığ1 ve \%17,45'nin böbrek rahatsızlı̆ bulunduğu belirlenmiştir. Bireylerin \%88'i herhangi bir rahatsızlığı için ilaç olarak tıbbi ve aromatik bitkileri tercih etmişlerdir.

\subsection{Bireylerin Tibbi Aromatik Bitkiyi Bilme veya} Tanıma Durumu

Bireylerin evlerinde gıda, tedavi, bitkisel çay, koku, tat katması, kozmetik veya, estetik gibi çeşitli amaçlar için kullandıkları tıbbi aromatik bitkileri tanıma bilme durumlarını belirlemek için tıbbi aromatik bitkilerin çeşitli tanımları anket yolu ile sorulmuştur. Sorular ve sorulara "evet tanım budur" diyenler Tablo 3 'te verilmiştir.

Tablo 3. Bireylerin Tıbbi Aromatik Bitkiyi Bilme veya Tanıma Durumu

\begin{tabular}{|c|c|c|c|}
\hline Sorulan Tanımlar & Puan & Frekans & $\%$ \\
\hline $\begin{array}{l}\text { Koku, renk ve tat bakımından tercih edilen bitkilere tıbbi } \\
\text { aromatik bitki denir. }\end{array}$ & 1 & 290 & 75,52 \\
\hline Bütün bitkiler tıbbı bitkidir. & 0 & 23 & 5,99 \\
\hline $\begin{array}{l}\text { Tıbbi bitkiler, ilk çağlardan beri uygulanan bir tedavi yoludur. } \\
\text { Günümüzde de hastalıkların önlenmesi, sağlıklı ve zinde bir } \\
\text { yaşam için tıbbi ve aromatik bitkiler tamamlayıcı bir tıp } \\
\text { yöntemidir. Aslında bitkiler yalnızca hasta olunca değil, hasta } \\
\text { olmamak için, bağışıklık sistemini destekleyici olarak da } \\
\text { kullanılır. }\end{array}$ & 1 & 324 & 84,38 \\
\hline $\begin{array}{l}\text { Yaygın olarak bulunan 12. yüzyıldan bu yana tek başına veya } \\
\text { değişik karışımlar ile tedavilerde ve eczacılık sanayinde } \\
\text { ilaçların yapımında etkin madde olarak kullanılan bitkilere } \\
\text { "tıbbi bitkiler" denmektedir. }\end{array}$ & 1 & 326 & 84,90 \\
\hline $\begin{array}{l}\text { Şifalı bitkiler, kısa sürede hastalıkları tedavi etmekten çok uzun } \\
\text { süreli bir yaşam biçimi olarak değerlendirilir. }\end{array}$ & 1 & 372 & 96,88 \\
\hline
\end{tabular}

Tablo 4'te bireylerin yoğun olarak tüketmeyi tercih ettikleri bitkiler verilmiştir. Bireylerin en fazla tüketmeyi tercih ettikleri bitkiler sirasıyla; kırmızı pul biber $(\% 85,42)$, nane $(\% 77,34)$, sarımsak $(\% 57,81)$, kekik $(\% 42,45)$ ve reyhan $(\% 28,13)$ 'dir.

Dicle (2010)'nin İzmir'de yaptığı çalışmasında tüketicilerin $\% 85,42$ gibi yüksek oranla en fazla tarçın bitkisini tükettiği belirlenmiştir. Doğu Anadolu Bölgesi'ndeki bireyler damak tadı ve alışkanlıktan dolayı kırmızı pul biberi fazla tüketirken Batı Bölgesindeki İzmir'de tarçın bitkisinin en yaygın olarak tüketilmektedir. Demircioğlu ve ark. (2007)'nın Ankara Merkez İlçesinde kadınların baharat kullanımı üzerine yaptıkları araştırmalarında katılımcıların İç ve Güneydoğu Anadolu Bölgesi'nden geldikleri ve \%83,5'inin kırmızı pul biberi yaygın olarak tükettikleri belirlenmiştir. 
Tablo 4. Bireylerin Tüketmeyi Tercih Ettikleri Tıbbi Aromatik Bitkiler

\begin{tabular}{lcclrc}
\hline $\begin{array}{l}\text { Kullanılan } \\
\text { Bitkiler }\end{array}$ & F & $\%$ & Kullanılan Bitkiler & F & $\%$ \\
\hline $\begin{array}{l}\text { Kırmızı Pul } \\
\text { Biber }\end{array}$ & 328 & 85,42 & Kişniş & 12 & 3,13 \\
\hline Nane & 297 & 77,34 & Ekinezya & 12 & 3,13 \\
\hline Sarımsak & 222 & 57,81 & Nar Çiçeği & 11 & 2,86 \\
\hline Kekik & 163 & 42,45 & Yaban Mersini & 10 & 2,60 \\
\hline Reyhan & 108 & 28,13 & Fesleğen & 10 & 2,60 \\
\hline Adaçayı & 85 & 22,14 & Avakado Yaprağı & 9 & 2,34 \\
\hline Ihlamur & 82 & 21,35 & Kantaron & 8 & 2,08 \\
\hline Dereotu & 71 & 18,49 & Melisa(Limon Otu) & 7 & 1,82 \\
\hline Çörek Otu & 64 & 16,67 & Keten Tohumu & 7 & 1,82 \\
\hline Kuşburnu & 57 & 14,84 & Gülhatmi & 6 & 1,56 \\
\hline Papatya & 52 & 13,54 & Civanperçemi & 4 & 1,04 \\
\hline Böğ̈rtlen & 38 & 9,90 & Hindiba & 3 & 0,78 \\
\hline Ebegümeci & 34 & 8,85 & Sütleğen & 3 & 0,78 \\
\hline Melengiç & 34 & 8,85 & Mercanköşk & 3 & 0,78 \\
\hline Isırgan & 30 & 7,81 & Oğul Otu & 3 & 0,78 \\
\hline Keçiboynuzu & 29 & 7,55 & Zerdeçal & 3 & 0,78 \\
\hline Salep & 23 & 5,99 & Efelek & 2 & 0,52 \\
\hline Biberiye & 14 & 3,65 & Kebere & 2 & 0,52 \\
\cline { 1 - 3 } Zencefil & 13 & 3,39 & & & \\
\hline
\end{tabular}

Tablo 5'te bireylerin tıbbi aromatik bitkileri kullanma nedenleri verilmiştir. Bireylerin tıbbi ve aromatik bitkileri en çok $(\% 77,60)$ gıda amaçlı tükettikleri belirlenmiştir. Bunu sirasiyla; koku ve tat katmaları $(\% 72,14)$, tedavi ve gida $(\% 27,34)$, bitkisel çay $(\% 26,30)$ ve kozmetik-estetik $(\% 3,91)$ amaçlı tüketim takip etmektedir.
Kocabaş ve Gedik (2016), Kahramanmaraş'ta semt pazarında satılan etnobotanik bitkilerin; gıda, tedavi ve süs amacıyla kullanıldığı sonucuna varmışlardır. Arya ve ark.(2012)'nın Hindistan'da yaptıkları çalışmalarında; tüketicilerin $\% 78,4$ 'ü tıbbı aromatik ürünleri sağlık için tükettikleri ortaya konulmuştur. Buradan; yurt içinde yapılan araştırmalarda tıbbi ve baharat bitkilerin kullanım nedenleri benzerlik gösterirken, yurt dışındaki araştırmalarda kullanım farklılıklar anlaşılabilir.

Tablo 5. Bireylerin Tibbi Aromatik Bitkileri KullanmaNedenleri

\begin{tabular}{lcc}
\hline \multicolumn{1}{c}{ Kullanma Nedenleri } & F & \% \\
\hline Tedavi & 30 & 7,81 \\
\hline Gıda & 298 & 77,60 \\
\hline Tedavi-Gıda & 105 & 27,34 \\
\hline Bitkisel çay & 101 & 26,30 \\
\hline Koku ve tat & 277 & 72,14 \\
\hline Kozmetik-estetik & 15 & 3,91 \\
\hline
\end{tabular}

\subsection{Bireylerin Tibbi ve Aromatik Bitkileri} Tüketmesini Etkileyen Faktörler

Araştırma kapsamında görüşülen bireylerin çeşitli tıbbi aromatik bitkilerden en az birini çeşitli nedenlerden dolayı doğrudan veya dolaylı tüketebileceği varsayılmıştır. Ancak bireylerin tükettikleri tıbbi aromatik bitkileri bilinçli olarak tüketme olasılığını etkileyen bazı faktörlerin belirlenmesi için binary logit analizi uygulanmıştır. Bireylerin tıbbi aromatik bitki tüketimini etkileyen faktörlerin analiz sonuçları Tablo 6 'da verilmiştir.

Tablo 6. Bireylerin Tıbbi Aromatik Bitkileri Bilinçli Tüketimini Etkileyen Faktörlerin Binary Logit Analiz Sonuçları

\begin{tabular}{|c|c|c|c|c|c|}
\hline & Kat Sayı & Standart Hata & $\mathrm{z}$ & $|z|>Z$ & Marjinal Etki \\
\hline Sabit & $-0,378$ & 0,745 & $-0,510$ & 0,612 & \\
\hline YAS & 0,011 & 0,018 & 0,590 & 0,557 & 0,002 \\
\hline CINSIYET & $-0,767 * * *$ & 0,267 & $-2,870$ & 0,004 & $-0,164 * * *$ \\
\hline MD & $1,131 * *$ & 0,450 & 2,510 & 0,012 & $0,242 * * *$ \\
\hline ED & 0,127 & 0,253 & 0,500 & 0,617 & 0,028 \\
\hline ESCALISM & $-0,579 *$ & 0,297 & $-1,950$ & 0,051 & $-0,127 * *$ \\
\hline GELIR & 0,002 & 0,01 & 0,240 & 0,809 & 0,005 \\
\hline FERT & $0,283 * * *$ & 0,102 & 2,770 & 0,006 & $0,062 * * *$ \\
\hline COCUK & $-1,164 * *$ & 0,496 & $-2,350$ & 0,019 & $-0,239 * * *$ \\
\hline KALP & 0,211 & 0,444 & 0,480 & 0,634 & 0,045 \\
\hline TANSIYON & $-0,145$ & 0,384 & $-0,380$ & 0,706 & $-0,032$ \\
\hline KOLESTER & 0,320 & 0,376 & 0,850 & 0,395 & 0,069 \\
\hline SEKER & $-0,655$ & 0,404 & $-1,620$ & 0,105 & $-0,149$ \\
\hline BOBREK & 0,194 & 0,461 & 0,420 & 0,674 & 0,042 \\
\hline ALTERNTF & $-0,448$ & 0,364 & $-1,230$ & 0,218 & $-0,101$ \\
\hline \multicolumn{6}{|c|}{ Not: $* * *, * *, *==>$ Önem seviyesinde temsili $\% 1, \% 5, \% 10$} \\
\hline
\end{tabular}

Bireylerin cinsiyet ve çocuk sahibi olma durumu $\% 1$ anlamlılık düzeyinde tıbbi ve aromatik bitkileri bilinçli tüketimini negatif yönde etkilerken, bireylerin medeni durumu ve hanede yaşayan birey sayısının bilinçli tüketimi pozitif yönde etkilediği belirlenmiştir. Kadınların erkeklere oranla \%16 olasılıkla daha bilinçli tüketim yaptığ söylenebilir. Bekar olmayan bireylerin bekarlara oranla \%24 olasılıkla daha bilinçli bir tıbbi aromatik bitki tüketicisi oldukları ortaya konulmuştur. Kişi sayısı bir fazla olan hanelerin tıbbi ve baharat bitkilerini daha bilinçli tüketme olasılığı diğer hanelere göre \%6 yüksektir. Çocuk sahibi olan bireylerin olmayanlara göre tıbbi ve aromatik bitkileri bilinçli tüketme olasılığ $1 \% 24$ daha azdır. 
Bireylerin eşlerinin çalışması ile tıbbi ve aromatik bitkileri bilinçli tüketmeleri arasında $\% 5$ önem seviyesinde anlamlı negatif bir ilişki bulunmuştur. Eşleri çalışmayan bireylerin eşleri çalışanlara göre tıbbi ve aromatik bitkileri bilinçli tüketme olasılığı \%13 daha yüksektir.

\section{Sonuç ve Öneriler}

Bireylerin isteyerek ya da kullanma sebebini bilerek tüketmeyi tercih etmesi, tüketeceği üründen yararlanma olasılığını artırmaktadır. Bu araştırmada bireylerin tıbbi ve aromatik bitkileri bilinçli tüketimlerini etkileyen faktörlerin belirlenmesi amaçlanmıştır. Doğu Anadolu Bölgesi'nin nüfus yoğunluğu bakımından üçüncü sırada olan Erzurum İlindeki bireylerin tıbbi aromatik bitkilerden en az birini tükettiği varsayılarak bilinçli tüketim yapanlar ile bilinçsiz tüketim yapanların karşılaştırılması istenmiştir.

Genç ve orta gelirli sayılabilecek bireylerle araştırma kapsamında görüşülmüş ve bireylerin eğitim durumları lise ve altı olduğu araştırma bulguları sonucunda ortaya konulmuştur. Bireylerin yarısından fazlasının evli çocuk sahibi olduğu belirlenmiştir. Araştırma sonucunda bireylerin büyük bir çoğunluğunun kalp, tansiyon, şeker, kolesterol gibi sağlık sorunları yaşamadığı belirlenmiştir.

$\mathrm{Bu}$ bilgiler 1şı̆̆ında bireylerin büyük bir çoğunluğunun tıbbi ve aromatik bitkileri bildiği ve tükettikleri belirlenmiştir.

Analiz sonucunda kadınların erkeklere oranla daha bilinçli tıbbi aromatik bitki tükettiği belirlenmiştir. Bunda kadınların tıbbi ve aromatik bitkilere; yemeklere tat ve aroma katması, çayın zayıflatma özelliği, kozmetik açıdan tüketilmesine daha fazla önem vermelerinin etkili olduğu ifade edilebilir.

Evli ve hane de yaşayan birey sayısı ile bilinçli tüketim arasında pozitif ilişki olması da olası bir sonuçtur. Çünkü bireylerin tıbbi aromatik ürünleri tüketme nedenlerinin en önemli sebebi olarak gıda ve tat-koku katması göz önüne alınırsa istatistiki olarak da anlamlı çıkması ispatı olmuştur. Sonuç olarak bireylerin \%39,80'ni tükettikleri tıbbi aromatik ürünleri bilmediği ya da bitkisel gelenek görenek yada alışkanlık gibi sebeplerden dolayı yani bilinçsiz tükettiği tespit edilmiştir. Kadınların daha çok tüketmeyi ve bilinçli olarak tüketmeyi tercih ettiği göz önüne alınarak bu yönde pazarlama stratejisi geliştirilmesi, reklam tanıtımlarının yapılması tüketimin daha bilinçli yapılmasına katkı sağlayacağı ifade edilebilir. Araştırma bölgesindeki bireylerin tıbbi aromatik bitkileri tüketimi bilinç düzeyleri çok düşük olmamakla beraber, kadınlar ve yalnız yaşayanların bu bitkileri daha çok tüketmeye meyilli oldukları tespit edilmiştir.

\section{Kaynakça}

Adıgüzel, F. \& Kızılaslan, N. (2016). İstanbul ilinde tıbbi, aromatik ve baharat bitkileri satışı yapan aktarların yapısal özellikleri ve mevzuat hakkındaki görüşleri. Anadolu Tarım Bilim. Dergisi, 31, 40-59.

Akbulut, S. \& Özkan, Z.C. (2016). Herbalist-Customer Profile in Medicinal and Aromatic Herbs Trade: A Case Study of Kahramanmaraş, Turkey. Kastamonu University Journal of Forestry Faculty, 16 (1), 246-252.
Akgül, A. \& Çevik, O. (2005). İstatistiksel Analiz Teknikleri. Emek Ofset Ltd. Şti. 2. Baskı. s.y. 428. Ankara.

Arya, V.,Thakur, R., Kumar, S. \& Kumar, S. (2012). Consumer buying behaviour towards Ayurvedicmedicines/products in Jogindernagar-A survey.Ayurpharm-International Journal of AyurvedaandAlliedSciences, 1(3), 60-64.

Bayram, E., Kırıc1, S., Tansı, S., Yılmaz, G., Arabacı, O., Kızıl, S. \& Telci,I.(2010). Tibbi ve Aromatik Bitkiler Üretiminin Arttırılması Olanakları. Türkiye Ziraat Mühendisliği VII. Teknik Kongresi Bildiriler Kitabı-I, 437-456, 11-15 Ocak, Ankara.

Berenson, M.L. \& Levine, D.M. (1996). Basic Business statisticsconceptsandapplications. sixth ed.. p. 837. prentice-hallinternational. New York.

Çelik, Y. (2014). Konya İlinde tıbbi ve aromatik bitki satışı yapan aktarların sosyo-ekonomik yapıları üzerine bir araştırma. Turkish Journal of Agricultural and Natural Sciences, 1(3), 369-376.

Demircioğlu, Y., Yaman, M. \& Şimşek, I. (2007). Kadınların baharat kullanım alışkanlıkları üzerine bir araştırma. TSKY Koruyucu Hekimlik Bülteni, 6(3).

Demirçivi, B.M. \& Altaş, A. (2016). Üniversite Öğrencilerinin Baharatlara İlişkin Bilgileri ve Tüketim Tercihleri: Aksaray Üniversitesinde Bir Uygulama. Journal of Tourism and Gastronomy Studies 4(4), 88112.

Dicle, M. (2010). İzmir İli Bornova İlçesinde Tıbbı Bitkilere İlişkin Tüketici Davranışlarının Belirlenmesi Üzerine Bir Araştırma. Ege Üniversitesi Fen Bilimleri Enstitüsü (Basılmış) Yüksek Lisans Tezi.

Faydaoğlu, E. \& Sürücüoğlu, M. S. (2011). Geçmişten günümüze tıbbi ve aromatik bitkilerin kullanılması ve ekonomik önemi. Kastamonu Üniversitesi Orman Fakültesi Dergisi, 11(1), 52-67.

Gujarati, N. D. (1992). Essential of Econometrics. McGrawHill. New York. 1999. Temel Ekonometri. Çeviren: Şenesen. Ü..Şenesen. G.G.. Literatür Yayıncılık, İstanbul.

Heinrich, M.,Barnes, J., Gibbons, S. \& Williamson, E.M. (2004). Fundementals of Pharmacognosy and Phytotherapy, Churchill Livingstone, Edinburgh.

Kızıloğlu, R. \& Kızılaslan, H. (2013).Consumer behaviors on foodpurchasingplaces: A casestudy of redmeatconsumption in Turkey, Research\&Reviews in Biosciences (RRBS), ISSN : 0974 - 7532, 7 (11), 453459.

Kızıloğlu, R. \& Kızılaslan, N. (2017). Kahramanmaraş İli Merkez İlçe Kırsalında Çiftçilerin Gübre Kullanım Durumu. Türk Tarım - Gıda Bilim ve Teknoloji Dergisi, 5(1): 18-23.

Kocabaş, Y.Z. \& Gedik, O.(2016). Kahramanmaraş İl Merkezi Semt Pazarlarında Satılan Bitkiler Hakkında Etnobotanik Araştırmalar. Iğdır Üni. Fen Bilimleri Enst. Der. / Iğdır Univ. J. Inst. Sci. \&Tech. 6(4): 41-50. 
Kökçü, B., Esen, O. \& Uysal İ. (2015). Medicinal plants sold in Çanakkale/Turkey city center herbalists. Biological Diversity and Conservation. 8(3), 80-91.

Lewin, R. (2000). Modern insanın Kökeni, TÜBİTAK Popüler Bilim Kitapları, Çeviri: N. Özüaydın, 7. basım, TÜBİTAK, Ankara.
Miran B. (2003). Temel istatistik. Ege Üniversitesi Basımevi. ISBN 975-9308800 Bornova İzmir.

Yüzbaşığlu, R. \& Ataoğlu, S.N. (2018). Tüketicilerin Kekik Tüketimini Etkileyen Faktörlerin Belirlenmesi: Manisa İli Salihli İlçesi Örneği. Ağrı İbrahim Çeçen Üniversitesi Sosyal Bilimler Enstitüsü Dergisi, 4(1), 259270. 
